\title{
An 18-Year Comparison of Control Methods for Wyoming Big Sagebrush in Southwestern Montana
}

\author{
CARL L. WAMBOLT AND GENE F. PAYNE
}

\section{Abstract}

Four Wyoming big sagebrush (A rtemisia tridentata ssp. wyomingensis Beetle and Young) control treatments: burning, spraying with 2,4-D, rotocutting, and plowing, along with no control (rest) were compared in southwestern Montana. Production data (excluding sagebrush) were collected 10 years and sagebrush canopy cover and understory basal cover were collected 8 years during the period 1963-1981. Sagebrush canopy was most effectively reduced by burning while plowing with seeding was least effective. Rest alone resulted in a $29 \%$ reduction in sagebrush canopy during the study period. By 1981, burning provided the most production from the dominant forage species (bluebunch wheatgrass (A gropyron spicatum (Pursh) Scribn.) and important vegetal classes, although burning and spraying were equally successful when production was totaled for all years sampled. Understory basal cover did not prove useful to evaluate treatment effectiveness.

Big sagebrush (Artemisia tridentata Nutt.) maintains an undeniably important role on rangelands in the Western United States. Big sagebrush occupies nearly 60 million hectares in this region (Beetle 1960). Relatively recent taxonomic advancements in the big sagebrush complex initiated by Beetle (1960) and Beetle and Young (1965) have encouraged research to expand our knowledge about the taxa in such diverse areas as further taxonomic refinement, ecological relationships, forage relationships, and manipulation of sagebrush ecosystems. Welch and McArthur (1979) emphasize the nature of big sagebrush by recognizing its aggressive, productive, and persistent habits which, along with its low preference for forage by cattle, are undoubtedly responsible for its having been the subject of many control projects. Blaisdell et al. (1982) emphasize that no one control technique will likely prove optimum under all conditions as big sagebrush control often is reported without consideration for inter-taxon variation. This complicates interpretation of many previous studies. In addition, few reports are available that follow vegetal reaction to big sagebrush control for more than a few years. This may partially explain apparent contradictions in the literature regarding effectiveness of various control and post-control techniques to suppress big sagebrush.

The objective of this study was to compare the effectiveness of 4 brush control treatments and no-control (rest) for Wyoming big sagebrush over the period 1963-1981. Effectiveness is evaluated through comparisons among treatments for forage production, sagebrush canopy cover, and basal cover of understory species.

\section{Study Area and Methods}

The study site is located in southwestern Montana approximately $27 \mathrm{~km}$ west of Dillon and $3 \mathrm{~km}$ northeast of Bannack at an elevation of $1,890 \mathrm{~m}$ on the west flank of Badger Pass. The area is administered by the Bureau of Land Management (BLM) and has been grazed by domestic livestock since the mid-1800's. The topography is moderately rolling, varying in slope from $0-8 \%$. The site comprises a Wyoming big sagebrush-bluebunch wheatgrass habitat type and has been dominated by those species throughout the study period. Although basin big sagebrush (Artemisia tridentata Nutt. ssp. tridentata) is found nearby, it occupies more mesic soils

\footnotetext{
Authors are associate professor and professor emeritus, Animal and Range Sciences Department, Montana State University, Bozeman, 59717.

The authors wish to express their appreciation to the Butte, Mont., District, Bureau of Land Management for the use and protection of the study site.

Manuscript accepted 21 October 1985.
}

resulting from drainage patterns and deeper soil development (Beetle and Young 1965, Barker and McKell 1983). Clay loams predominate in surface and subsurface soils with loams being less common. The solum extends 30 to $35 \mathrm{~cm}$ to a strongly calcareous $C$ horizon. Erosion had thinned or completely removed the $A$ horizon. The average annual precipitation is approximately 310 $\mathrm{mm}$ with peak precipitation occurring in May and June.

We utilized a randomized complete block design of 4 replicates in the experiment. Treatment plots were $27 \mathrm{~m} \times 46 \mathrm{~m}$ in 2 replicates and $31 \mathrm{~m} \times 46 \mathrm{~m}$ in the other 2 replicates. Most treatment plots were separated by roadways seeded to crested wheatgrass (Agropyron cristatum (L.) Gaertn.) Analysis of variance was used to evaluate relationships among measured factors.

Livestock grazing was excluded from the study site by an exclosure fence after May, 1963. Chemical, plow, and rotocut treatments were applied on 18-19 June, 22 June, and 6 July 1963, respectively. The burn treatment was accomplished after 4 September 1964 after being attempted in the autumn of 1963 when fuel conditions prohibited burning. Chemical treatment consisted of an application of 2,4-D ester in water at the rate of approximately 1.68 $\mathrm{kg} /$ ha with a surfactant from a ground sprayer. Plowing was accomplished with a disc plow similar to the popular Brushland plow of the era (Larson 1982) which Blaisdell et al. (1982) considered very effective. Plowed plots were broadcast seeded with approximately $9 \mathrm{~kg} /$ ha of bluebunch wheatgrass seed from a local source, a practice considered necessary with this severe treatment (Blaisdell et al. 1982). The rotary cutter used was similar to the Bush Hog (Larson 1982). Burning was difficult due to a barely adequate fuel base (Beardall and Sylvester 1976) and some sagebrush plants had to be burned individually.

Within each treatment replicate, 6 permanent $15.24-\mathrm{m}$ transect lines (Canfield 1941) were randomly established to determine Wyoming big sagebrush crown cover by line intercept. Data were taken in tenths of feet (approximately $3 \mathrm{~cm}$ units). Openings in the live canopy larger than $3 \mathrm{~cm}(0.1 \mathrm{ft}$.) were recorded as nonsagebrush intercepts. It should be emphasized that this method gives lower values than those obtained by line intercepts of sagebrush plant perimeters or by the Daubenmire (1959) method. Intercepts of such perimeters ignore open spaces and dead branches within the perimeter. This is important in comparing other research results with ours and when reading such publications as Britton and Ralphs (1979) which set cover standards for sagebrush control operations. We believe our method accurately measures changes in live sagebrush cover, significant in considering the ecological status of big sagebrush through time. It is unfortunate that most management publications set sagebrush cover standards without defining the measurement basis. Along each of the $15.24-\mathrm{m}$ transects, 2 permanent $1.22-\mathrm{m}$ transects were randomly selected to read basal cover of all plants. These data were recorded in hundredths of feet (approximately 3-mm units) of line intercept by species, litter, rock, and bare ground.

Production data in each treatment replicate were obtained by clipping 5 circular plots of $0.5 \mathrm{~m}^{2}$ randomly spaced on a diagonal line beginning and ending no closer than 6 meters from the treatment corners. During the randomization process, the centers of the $0.5-\mathrm{m}^{2}$ plots were located at least $2.13 \mathrm{~m}$ apart to avoid disturbance of plants when clipping adjacent plots. In each year when production data were collected, the diagonal sampled in the rectangular 
treatment was alternated to minimize effects of previous sampling. Plant material was oven dried at $65^{\circ} \mathrm{C}$ for 1 week before weighing. All measurements were taken as close to the peak of standing crop production as practical. Thus, grass and shrub phenology were similar each year at the time data were taken. Canopy and basal cover were recorded 8 years and production 10 years during the 18-year study.

\section{Results and Discussion}

Wyoming big sagebrush canopy cover provides a partial basis for evaluation of treatment effectiveness throughout the study period (Figures 1 and 2). The homogeneity of the sagebrush cover in the 1963 pretreatment data is evident by the lack of statistical significance among the treatment means. There was a significant reduction in sagebrush canopy cover the first year after application of the sagebrush control treatments (1965 for burn and 1964 for other treatments). The longevity of this reduction has varied considerably among the treatments. The 18 years of the study allowed ample opportunity for sagebrush reoccupation under a variety of weather conditions.

Burning completely destroyed the stands of Wyoming big sagebrush. There was essentially no re-establishment of sagebrush through 1970, 6 years after burning, in spite of the availability of sagebrush seeds from rest (untreated) plots and plants growing outside the study exclosure. Up to 1967 , only the spray technique had been as effective as burning in sustaining reductions of sagebrush canopy. From 1970 on, burned plots had significantly less sagebrush canopy than any other treatment. Although some reoccupation of sagebrush on the burned plots was evident by 1981 , its canopy cover was still less than $2 \%$ compared to $10.5-16 \%$ in the other treatments.

The apparent success of burning in this study may agree with the observations and data of Harniss and Murray (1973), who
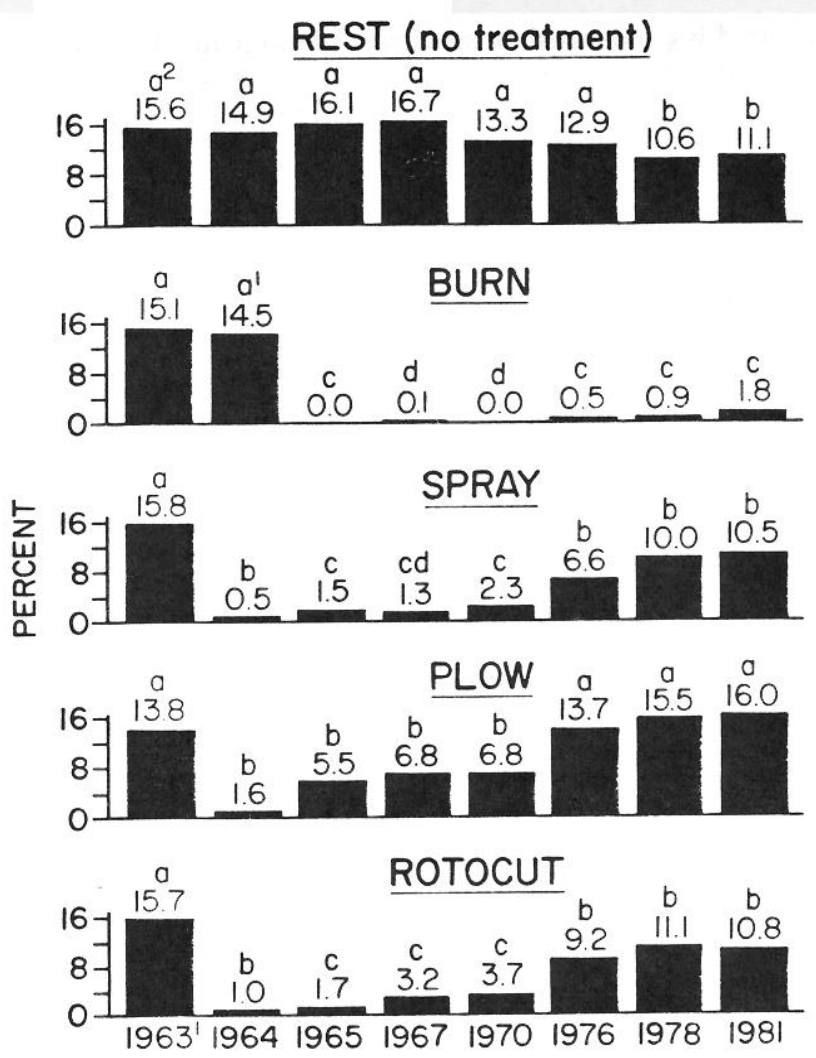

Fig. 1. Mean percent canopy cover of Wyoming big sagebrush in relation to year and sagebrush control treatment.

'Data are pre-brush control.

${ }^{2}$ Differences between mean values within years are significant $(P<0.05)$ when followed by a different letter according to Duncan's multiple range test.
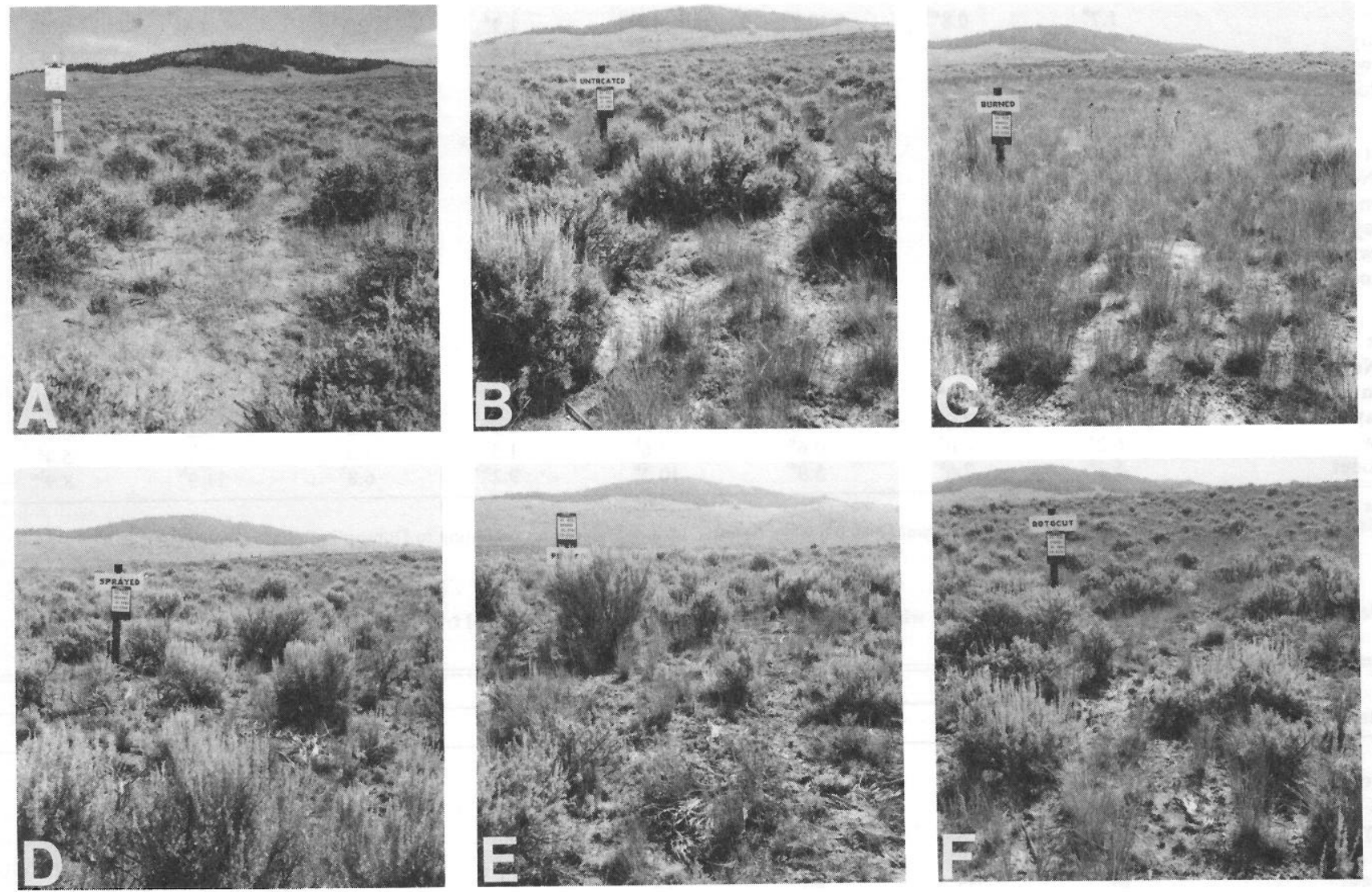

Fig. 2. The study area before sagebrush control in $1962(A)$, and representative views of sagebrush treatments in $1980: B$ - no treatment (rest), $C$-burn, $D$ -spray, E-plow, and F-rotocut. 
reported big sagebrush in southeast Idaho made little increase in production for 12 years following burning. However, they added that in the next 18 years mountain big sagebrush (Artemisia tridentata ssp. vaseyana (Rydb.) Beetle) made substantial production increases while other vegetal components decreased. There was only 1 year of rest after burning before grazing with sheep, unlike our study which excluded grazing through its duration. The long periods between sampling make it difficult to be certain how the results of Harniss and Murray (1973) should be compared to our findings.

Rotocut and spray treatments maintained similar sagebrush canopy cover throughout the duration of the study. Canopy cover in these sagebrush control treatments became similar to the rest treatments in 1978. Spraying was about as effective as burning in reducing sagebrush canopy during the first 4 years after treatment, but after 1967, increases of sagebrush canopy cover in the spray and rotocut treatments occurred much faster than in the burn treatment. Unpublished data indicate that some very small sage- brush plants were protected from the spray by other vegetation and formed the major basis for later canopy cover increases. Rotocutting at 2 to 3 inches above ground level also left very small plants intact.

Plowing was the least effective method used in this study. A scattering of mature sagebrush plants remained on the plowed plots, providing a seed source for rapid reinvasion. The plowing probably reduced competition to provide a favorable seedbed for new sagebrush establishment. The removal of competition also provided a very favorable habitat for the remaining sagebrush plants to expand in size and to produce very large amounts of seed in the following years. By the second year after treatment, Wyoming big sagebrush canopy had increased in the plowed treatments to become significantly higher than any of the other treatments except rest. This relative ranking was maintained until 1976 when the sagebrush cover in the plowed treatment equalled that in the rest treatment. By 1978, sagebrush canopy cover in the plowed treatment was significantly greater than all other treatments, including rest.

Table 1. Mean percent basal cover by year for important species and vegetation classes having significant differences among Wyoming big sagebrush control trentments.

\begin{tabular}{|c|c|c|c|c|c|c|c|c|}
\hline \multirow[b]{2}{*}{ Control Method } & \multicolumn{8}{|c|}{ Year } \\
\hline & 19631 & 1964 & 1965 & 1967 & 1970 & 1976 & 1978 & 1981 \\
\hline & \multicolumn{8}{|c|}{ Bluebunch Wheatgrass } \\
\hline $\begin{array}{l}\text { Rest } \\
\text { (No Treatment) }\end{array}$ & $0.7^{.2}$ & $0.3^{n}$ & $0.2^{\mathrm{c}}$ & $1.4^{\mathrm{c}}$ & $1.6^{\mathrm{bc}}$ & $1.1^{\mathrm{b}}$ & $0.6^{*}$ & $2.9^{\mathrm{a}}$ \\
\hline Burn & $0.5^{\mathrm{a}}$ & $0.2^{\mathrm{al}}$ & $0.2^{\mathrm{c}}$ & $2.5^{\mathrm{bc}}$ & $2.8^{\mathrm{ab}}$ & $2.1^{\mathrm{a}}$ & $1.7^{\mathrm{a}}$ & $1.8^{\mathrm{abc}}$ \\
\hline Spray & $0.6^{\circ}$ & $0.4^{n}$ & $0.8^{n}$ & $5.0^{\circ}$ & $2.9^{\mathrm{ab}}$ & $1.3^{\mathrm{ab}}$ & $1.3^{n}$ & $2.1^{\text {ab }}$ \\
\hline Plow & $0.8^{a}$ & $0.0^{b}$ & $0.4^{b c}$ & $3.8^{\mathrm{ab}}$ & $0.7^{\mathrm{c}}$ & $0.7^{b}$ & $1.9^{\mathrm{a}}$ & $1.4^{\mathrm{bc}}$ \\
\hline Rotocut & $0.8^{\star}$ & $0.4^{a}$ & $0.7^{\mathrm{ab}}$ & $3.7^{\mathrm{ab}}$ & $3.3^{2}$ & $0.8^{\mathrm{b}}$ & $0.5^{\star}$ & $0.8^{\mathrm{c}}$ \\
\hline $\begin{array}{l}\text { Rest } \\
\text { (No Treatment) }\end{array}$ & $1.8^{\mathrm{a}}$ & $0.9^{\mathrm{a}}$ & $0.5^{\mathrm{ab}}$ & $\begin{array}{l}\text { Sandt } \\
5.2^{\mathrm{a}}\end{array}$ & $\begin{array}{l}\text { egrass } \\
1.5^{\mathrm{a}}\end{array}$ & $1.4^{\mathrm{b}}$ & $1.9^{\mathrm{n}}$ & $2.3^{\mathrm{n}}$ \\
\hline Burn & $1.7^{\star}$ & $0.8^{\wedge 1}$ & $0.7^{\mathrm{a}}$ & $4.3^{\mathrm{a}}$ & $1.9^{a}$ & $2.5^{\mathrm{a}}$ & $1.8^{\mathrm{a}}$ & $1.2^{\mathrm{b}}$ \\
\hline Spray & $1.2^{a}$ & $0.9^{\alpha}$ & $0.7^{\mathrm{a}}$ & $4.2^{\mathrm{a}}$ & $1.4^{\mathrm{a}}$ & $1.3^{\mathrm{b}}$ & $1.2^{\mathrm{a}}$ & $1.4^{b}$ \\
\hline Plow & $1.5^{\mathrm{a}}$ & $0.1^{b}$ & $0.1^{b}$ & $0.3^{b}$ & $0.0^{\mathrm{b}}$ & $0.1^{\mathrm{c}}$ & $0.2^{b}$ & $0.7^{b}$ \\
\hline Rotocut & $1.2^{\mathrm{a}}$ & $0.7^{a}$ & $0.7^{\mathrm{a}}$ & $4.4^{2}$ & $1.2^{\mathrm{a}}$ & $0.6^{\mathrm{bc}}$ & $1.6^{\mathrm{a}}$ & $1.0^{\mathrm{b}}$ \\
\hline $\begin{array}{l}\text { Rest } \\
\text { (No Treatment) }\end{array}$ & $2.5^{\mathrm{a}}$ & $1.2^{\star}$ & $0.7^{\mathrm{b}}$ & $\begin{array}{c}\text { Total P } \\
6.7^{\mathrm{ab}}\end{array}$ & $\begin{array}{c}\text { Grasses } \\
3.2^{\mathrm{A}}\end{array}$ & $2.6^{\mathrm{bc}}$ & $3.0^{\mathrm{a}}$ & $5.2^{2}$ \\
\hline Burn & $2.2^{2}$ & $1.1^{\star 1}$ & $0.9^{\mathrm{ab}}$ & $7.1^{\mathrm{ab}}$ & $4.8^{\mathrm{a}}$ & $4.7^{\mathrm{a}}$ & $3.7^{\mathrm{a}}$ & $3.0^{b c}$ \\
\hline Spray & $1.8^{\mathrm{n}}$ & $1.3^{a}$ & $1.5^{\mathrm{a}}$ & $9.6^{\mathrm{a}}$ & $4.3^{\mathrm{a}}$ & $2.8^{\mathrm{b}}$ & $2.8^{\mathrm{a}}$ & $4.0^{\mathrm{ab}}$ \\
\hline Plow & $2.4^{\mathrm{a}}$ & $0.1^{b}$ & $0.5^{b}$ & $4.3^{b}$ & $0.8^{b}$ & $1.0^{\mathrm{d}}$ & $2.4^{\mathrm{a}}$ & $2.5^{\mathrm{be}}$ \\
\hline Rotocut & $2.0^{\mathrm{a}}$ & $1.1^{\circ}$ & $1.4^{\mathrm{a}}$ & $8.4^{\mathrm{a}}$ & $4.6^{\mathrm{a}}$ & $1.4^{\mathrm{cd}}$ & $2.4^{a}$ & $1.8^{\mathrm{e}}$ \\
\hline $\begin{array}{l}\text { Rest } \\
\text { (No Treatment) }\end{array}$ & $6.0^{n}$ & $8.4^{n}$ & $4.2^{\mathrm{n}}$ & $\begin{array}{l}\text { Total P } \\
8.3^{\mathrm{a}}\end{array}$ & $\begin{array}{c}\text { Forbs } \\
6.0^{b}\end{array}$ & $7.0^{\mathrm{b}}$ & $10.2^{b}$ & $11.5^{\mathrm{ab}}$ \\
\hline Burn & $8.2^{a}$ & $9.3^{a 1}$ & $6.2^{\circ}$ & $11.5^{\mathrm{a}}$ & $10.2^{\mathrm{a}}$ & $9.8^{\mathrm{n}}$ & $16.9^{a}$ & $13.9^{2}$ \\
\hline Spray & $4.8^{\mathrm{n}}$ & $3.6^{b}$ & $1.8^{b}$ & $1.8^{\mathrm{b}}$ & $2.2^{\mathrm{c}}$ & $3.0^{\mathrm{c}}$ & $5.2^{c}$ & $6.6^{c}$ \\
\hline Plow & $6.2^{\mathrm{n}}$ & $1.0^{\mathrm{b}}$ & $0.6^{\mathrm{b}}$ & $3.6^{\mathrm{b}}$ & $1.5^{\mathrm{c}}$ & $3.0^{\mathrm{c}}$ & $5.1^{c}$ & $5.4^{\mathrm{c}}$ \\
\hline Rotocut & $5.3^{\mathrm{n}}$ & $7.6^{\circ}$ & $5.0^{\mathrm{a}}$ & $10.3^{n}$ & $9.2^{\mathrm{ab}}$ & $6.8^{b}$ & $11.9^{\mathrm{b}}$ & $8.9^{b c}$ \\
\hline
\end{tabular}

1Data are pre-brush control.

${ }^{2}$ Differences between mean values within years are significant $(P<0.05)$ when followed by a different letter according to Duncan's multiple range test.

Table 2. Mean percent bare ground by year found within different Wyoming big sagebrush control treatments.

\begin{tabular}{|c|c|c|c|c|c|c|c|c|}
\hline \multirow[b]{2}{*}{ Control Method } & \multicolumn{8}{|c|}{ Year } \\
\hline & 19631 & 1964 & 1965 & 1967 & 1970 & 1976 & 1978 & 1981 \\
\hline $\begin{array}{l}\text { Rest } \\
\text { (No Treatment) }\end{array}$ & $69^{22}$ & $52^{b}$ & $57^{b}$ & $28^{b}$ & $48^{\mathrm{B}}$ & $53^{\mathrm{ab}}$ & $50^{\circ}$ & $55^{a}$ \\
\hline Burn & $67 a$ & $57^{\mathrm{b1}}$ & $73^{a}$ & $46^{\mathrm{a}}$ & $37^{\mathrm{b}}$ & $53^{\mathrm{ab}}$ & $46^{* b}$ & $45^{\circ}$ \\
\hline Spray & $54^{b}$ & $56^{b}$ & $46^{c}$ & $23^{\mathrm{b}}$ & $28^{\mathrm{b}}$ & $44^{c}$ & $38^{\mathrm{b}}$ & $46^{\circ}$ \\
\hline Plow & $62^{a b}$ & $78^{a}$ & $76^{\mathrm{a}}$ & $32^{b}$ & $30^{\mathrm{b}}$ & $56^{\mathrm{a}}$ & $49^{n}$ & $52^{\circ}$ \\
\hline Rotocut & $61^{\mathrm{ab}}$ & $38^{\mathrm{c}}$ & $40^{c}$ & $13^{c}$ & $29^{b}$ & $46^{\mathrm{bc}}$ & $42^{\mathrm{ab}}$ & $49^{n}$ \\
\hline
\end{tabular}

Data are pre-brush control.

${ }^{2}$ Differences between mean values within years are significant $(P<0.05)$ when followed by a different letter according to Duncan's multiple range test. 
Johnson and Payne (1968) also working in southwestern Montana were unable to find statistically significant differences between sagebrush reinvasion on numerous range sites that were sprayed and sites plowed and seeded to grass. However, we found a significantly greater sagebrush canopy cover on plowed-seeded plots when compared to sprayed plots as early as 1965 , the second year following treatment, and the relationship held for the duration of th study. Johnson and Payne (1968) found sagebrush re-establishment to be highly associated with the survival of mature shrubs left by an incomplete brush control treatment or the result of a scattering of a new sagebrush seed crop when treatments such as plowing were carried out in the late autumn after seed maturity. All treatments in our study were accomplished prior to seed maturation. Survival of mature shrubs in the plowed treatments offers the best explanation for rapid re-establishment of sagebrush in that treatment.

The rest plots might have served as a seed source, but Johnson and Payne (1968) indicated very little spread of seed from parent plants. The slowness of sagebrush canopy increase in the burn treatment supports their findings.

In our study Wyoming big sagebrush canopy cover decreased $29 \%$ on the rested sites, despite the taxon's apparent adaptability to the environment. This decline was in evidence by 1970 and continued until 1978 and 1981 while the species canopy cover increased with other treatments. Others (Robertson 1971, Anderson and Holte 1981, Holechek and Stephenson 1983) have reported the opposite as big sagebrush taxa increased with grazing exclusion in their studies.

Table 1 summarizes treatment means of plant understory basal cover by year for the species and vegetal classes most important on the study site. Bluebunch wheatgrass, Sandberg bluegrass (Poa sandbergii Vasey) and total perennial grasses had no significant composition differences among the study plots prior to sagebrush treatment in 1963 . Their basal cover remained statistically the same as the rest treatment the year following sagebrush control with the exception of the plowed treatment where significantly less of these

Table 3. Mean production ( $\mathrm{Kg} / \mathrm{ha}$ ) by year for important species and vegetation classes having significant differences among $W_{y o m i n g}$ big sagebrush control treatments.

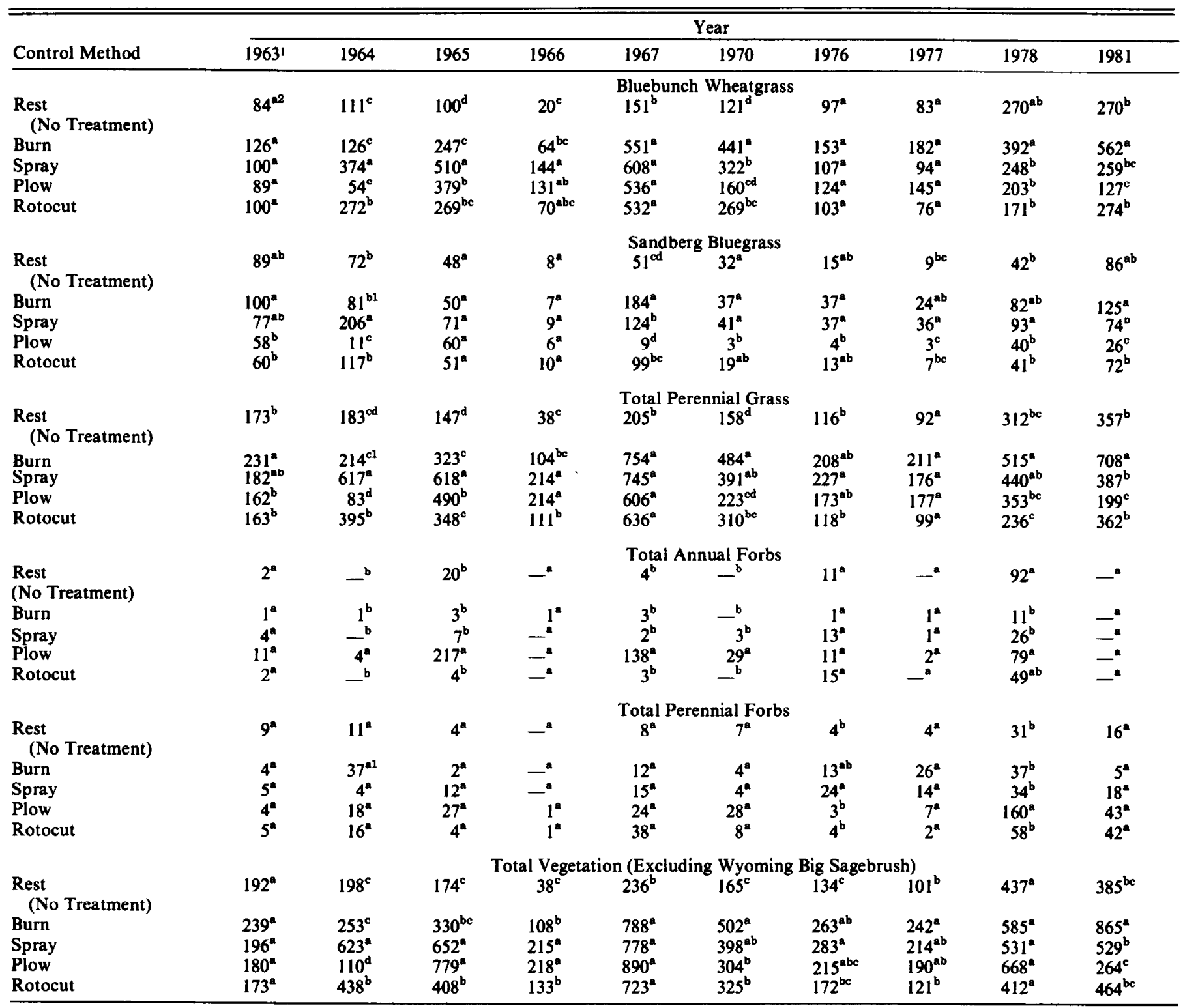

'Data are pre-brush control.

Differenes between mean values within years are significant $(\mathcal{P}<0.05)$ when followed by a different letter according to Duncan's multiple range test. 
Table 4. Mean production totals ( $\mathrm{Kg} / \mathrm{ha}$ ) for important species and vegetation clasees having significant differences among $\mathrm{Wyoming}$ big sagebrush control treatments. Production was sampled 10 times during the period 1963-1981.

\begin{tabular}{|c|c|c|c|c|c|c|}
\hline Control method & $\begin{array}{l}\text { Bluebunch } \\
\text { wheatgrass }\end{array}$ & $\begin{array}{l}\text { Sandberg } \\
\text { bluegrass }\end{array}$ & $\begin{array}{c}\text { Total perennial } \\
\text { grass }\end{array}$ & $\begin{array}{l}\text { Total annual } \\
\text { forbs }\end{array}$ & $\begin{array}{c}\text { Total perennial } \\
\text { forbs }\end{array}$ & $\begin{array}{l}\text { Total vegeta } \\
\text { production }\end{array}$ \\
\hline $\begin{array}{l}\text { Rest } \\
\text { (No Treatment) }\end{array}$ & $1304^{\mathrm{cl}}$ & $452^{b}$ & $1780^{\circ}$ & $130^{b}$ & $94^{b}$ & $2059^{d}$ \\
\hline Burn & $2841^{\bullet}$ & $728^{a}$ & $3751^{\mathrm{a}}$ & $22^{b}$ & $141^{b}$ & $4175^{a b}$ \\
\hline Spray & $2779^{\prime}$ & $779^{a}$ & $4019^{a}$ & $56^{b}$ & $129^{b}$ & $4441^{\circ}$ \\
\hline Plow & $1947^{b}$ & $218^{c}$ & $2679^{\mathrm{b}}$ & $490^{\circ}$ & $314^{a}$ & $3837^{\mathrm{bc}}$ \\
\hline Rotocut & $2136^{b}$ & $489^{b}$ & $2779^{b}$ & $72^{b}$ & $178^{b}$ & $3369^{c}$ \\
\hline
\end{tabular}

'Differences between mean values within columns are significant $(P<0.05)$ when followed by a different letter according to Duncan's multiple range test.

species was found.

Bluebunch wheatgrass increased in all big sagebrush treatments (removal and rest) by 1967 . Some of the differences among treatments were not statistically significant. The differences were less obvious in 1970 and 1976 . By 1978 there were no statistically significant differences among treatments, including rest. By 1981 , the plowed and rotocut treatments had less basal cover of bluebunch wheatgrass than any of the brush control treatments or rest. Sandberg bluegrass remained consistently lowest in the plowed areas through 1981 . There were no clear patterns in other treatments until 1981 when the rest treatment contained a significantly higher basal cover of the species. There were no significant differences in basal cover of all perennial grasses among the sagebrush treatments by 1978 , but in 1981 the rested and sprayed areas had significantly greater basal coverage of perennial grasses than the othe treatments at $5.2 \%$ and $4.0 \%$ respectively.

Overall, basal cover of understory plants did not provide as much insight into plant community changes as did sagebrush canopy cover or forage production. We suspect this is due primarily to inadequate sampling. The fact that some rather wide differences lacked statistical significance suggests this. However, basal cover sampling as done in this study is extremely time consuming.

Percentage of bare ground found within the treatments varied greatly through the study period regardless of treatment (Table 2). It is interesting that by 1981 no significant differences in percent bare ground were found among the sagebrush treatments. When the study was initiated, the plots receiving the spray treatment did contain significantly less bare ground than the rest or burned plots. The rotocut treatment had significantly less bare ground than other treatments through 1967 due to the plant material left lying on the ground by the rotocutting. This difference disappeared by 1970. It should not be expected that there necessarily would be a close relationship between bare ground and the vegetation cover reported in Table 1. Annuals, mulch cover, and other factors affect the amount of bare ground.

The annual production of important understory species and vegetal classes having some statistically significant differences among treatment means are presented in Table 3. Means of bluebunch wheatgrass and total vegetal production (excluding Wyoming big sagebrush) showed no significant differences among treatments prior to application of sagebrush control measures in 1963. However, in 1963 the plots to be burned did have a significantly higher production of Sandberg bluegrass than those plowed and rotocut and more total perennial grasses than the other treatment plots with the exception of those sprayed.

Bluebunch wheatgrass responded with greatly increased production the year following sagebrush control by spraying, burning, and rotocutting. Production ranged from 2.5 to over 3 times that of the rest plots. Production in the plowed plots was about half that in the rest plots the first year after treatment.

With few exceptions all sagebrush removal treatments had significantly higher bluebunch wheatgrass yields than the rest treatment in the next 3 test years $(1966,1967,1970)$. In the remaining test years $(1976,1977,1978,1981)$, bluebunch wheatgrass yields in the rest plots had increased to the point that there were few significant differences between rest and sagebrush removal.

Beginning in 1970, bluebunch wheatgrass yields were higher on the burn treatment than all other treatments. These higher values were not significant in 1976 and 1977 but in 1981 stood alone at more than double all other treatments. These results would appear to contradict the conclusions of Mueggler and Blaisdell (1958) and Wright et al. (1979) that subsequent bluebunch wheatgrass production can be expected to be reduced to some extent by fire. Our results would indicate that whether or not this is the case depends on the nature of the fire and probably other factors. The limited non-sagebrush fuel on our burned plots resulted in a comparatively cool burn except immediately under the sagebrush plants.

There were few significant differences in Sandberg bluegrass production among burning, spraying, rotocutting, and rest treatments until 1981 when production in the burn was significantly higher than the spray and rotocut treatments and higher, but not significantly greater than rest treatments. Sandberg bluegrass evidently never fully recovered from the disturbance created in the plowed plots, showing consistently low production in this treatment.

The production response of total perennial grasses and total vegetation followed the pattern of bluebunch wheatgrass, the major component of both categories. Perennial grasses did take the most immediate advantage of the release from sagebrush competition as Mueggler and Blaisdell (1958) indicated they might.

In 1981, the burn treatment seemed to show a clear superiority for production of perennial grasses while the plowed areas were producing significantly less perennial grass than any other treatment. The rest, spray, and rotocut treatments were producing perennial grasses at about the same rate in the final year of production checks. Herbaceous vegetation did not generally reach a maximum production within a few years after treatment and subsequently decline, as predicted by Blaisdell et al. (1982).

Total vegetal production was similar among all of the control measures by 1967 when they were producing over 3 times as much plant aerial biomass (excluding sagebrush) as the rested areas. By 1978 , the rested range production had increased enough that there was no significant difference among the 5 treatments. This apparently was related to the reduction of sagebrush cover on the rest treatment. Closer examination of the 1965,1967 , and 1978 production data shows that the plowed treatment came up to the level of the other treatments in total vegetal production. This was from major contributions by annual and perennial forbs.

In 1981, the burn areas were producing significantly greater amounts of plant biomass (excluding Wyoming big sagebrush) than the other treatments and over 3 times as much as the plowed areas. Welch and McArthur (1979) point out, and Mueggler and Blaisdell (1958) and Harniss and Murray (1973) support with data, that big sagebrush is capable of yielding substantial amounts of foliage and that maximum vegetation yields occur when sagebrush is included in the vegetation complex on sagebrush grass habitat types. Thus, it was a shortcoming of this study to not measure production of Wyoming big sagebrush for a better overall understanding of production dynamics following sagebrush con- 
trol. The relative rankings of total vegetal production among the treatments would likely shift from results presented in Table 3 if production of Wyoming big sagebrush were included.

The plowed treatments in general seemed to have the greatest production of both annual and perennial forbs throughout the study period. The contribution of annual forbs in the plowed treatment was particularly great in 1965 and 1967 . In 1978, perennial forb production in the plowed treatment was 3 to 5 times as great as in the other treatments. Although the production of annual and perennial forbs in the spray plots was less than in other sagebrush control treatments immediately following their application, the differences were not significant as might be expected (Mueggler and Blaisdell 1958). While half shrubs occurred rather frequently, they did not contribute great amounts to total production figures in any treatment. There were no significant differences observed among treatments for half shrub species throughout the study. Shrubs other than Wyoming big sagebrush were nearly non-existent until 1978. In 1981, burn and spray treatments contained $106.8 \mathrm{~kg} / \mathrm{ha}$ and $81.4 \mathrm{~kg} / \mathrm{ha}$ of rubber rabbitbrush (Chrysothamnus nauseosus (Pall.) Britt.) respectively, contrasted to trace quantities in the other treatments.

The production totals for important species and vegetal classes over the 10 sampling years are of value to compare treatment effectiveness over the duration of the study (Table 4). Since the cumulative effects on production of sagebrush control methods over time are indicative of economic return, they provide insight beyond a simple comparison at one point in time. Burning and spraying resulted in significantly greater production of bluebunch wheatgrass, Sandberg bluegrass, total perennial grasses and total vegetal production than the other treatments. Plowing produced more annual and perennial forbs and less Sandberg bluegrass than other treatments. Thus, over the length of the study burning and spraying with 2,4-D were equally successful in increasing production of forage. However, the advantage of spraying appears to have been rather short-lived while burning proved to be superior in increasing production during the latter years of the study. Further, burning would likely have an advantage over spraying in accumulative production if data were collected over additional growing seasons beyond 1981, since treatment effects still are obvious.

Johnson (1969), also working with Wyoming big sagebrush, concluded the longevity of chemical control was between 14 and 17 years on areas not grazed by livestock. Our study agrees with this conclusion. At 15 years after treatment, the chemical control, plow, and rotocut treatments no longer had significantly different sagebrush cover than the rest treatment. This comes from a $32 \%$ decrease in sagebrush cover by 1978 in the rest plots as well as major increases in the other treatments.

We did not make statistical comparisons of basal cover and production data among years for forage species because of unknown variations in environment. The declines in forage production on our treatments appear to be closely related to reinvasion of sagebrush, unlike the experience of Thilenius and Brown (1974).

\section{Conclusions}

In conclusion, certain points brought out by this study would seem relevant to land managers working in a similar habitat type. If control of Wyoming big sagebrush to increase understory production is the management objective, then spraying with 2,4-D and burning are more effective than rotocutting or plowing and seed- ing. On a long-term basis, (more than 10-15 years) burning apparently can be more effective than spraying in suppressing Wyoming big sagebrush. But an effective burn in Wyoming big sagebrush habitat types may often be difficult to realize due to less than adequate fuel bases. Our results are interpreted to show an inherent danger in drawing conclusions on the effectiveness of sagebrush control techniques with only a few years of observations. Finally, if quick results are not necessary, grazing management alone may allow opportunity to improve production from Wyoming big sagebrush understory. Sagebrush cover was reduced from rest alone during our study period, and it seems likely that if sagebrush production was considered in this habitat type, total production without brush control would exceed that on treated areas several years after treatment under many circumstances.

\section{Literature Cited}

Anderson, J.E., and K.E. Holte. 1981. Vegetation development over 25 years without grazing on sagebrush-dominated rangeland in southeastern Idaho. J. Range Manage. 34:25-29.

Barker, J.R., and C.M. McKell. 1983. Habitat differences between basin and Wyoming big sagebrush in contiguous populations. J. Range Manage. $36: 450-454$.

Beardall, L.E., and V.E. Sylvester. 1976. Spring burning for removal of sagebrush competition in Nevada. Proc. Tall Timbers Fire Ecol. Cong. 14:539-547.

Beetle, A.A. 1960. A study of sagebrush-Section Tridentatae of Artemisia. Wyoming Agr. Exp. Sta. Bull. 368.

Beetle, A.A., and A. Young. 1965. A third subspecies in the Artemisia tridentata complex. Rhodora 67:405-406.

Blaisdell, J.P., R.B. Murray, and E.D. McArthur. 1982. Managing intermountain rangelands-sagebrush-grass ranges. USDA Forest Serv. Gen. Tech. Rep. INT-134.

Britton, C.M., and M.H. Ralphs. 1979. Use of fire as a management tool in sagebrush ecosystems. p. 101-109. In: The Sagebrush Ecosystem: A Symposium. Utah State Univ., Coll. Natur. Resources, Logan.

Canfield, R.H. 1941. Application of the line-interception method in sampling range vegetation. J. Forest. 39:388-394.

Daubenmire, R.F. 1959. A canopy-coverage method of vegetational analysis. Northwest Sci. 33:43-64.

Harniss, R.0., and R.B. Murray. 1973. Thirty years of vegetal change following burning of sagebrush-grass range. J. Range Manage. 26:322-325.

Holechek, J.L., and T. Stephenson. 1983. Comparison of big sagebrush vegetation in north-central New Mexico under moderately grazed and grazing excluded conditions. J. Range Manage. 36:455-456.

Johnson, W.M. 1969. Life expectancy of a sagebrush control in central Wyoming. J. Range Manage. 22:177-182.

Johnson, R.J., and G.F. Payne. 1968. Sagebrush reinvasion as affected by some environmental influences. J. Range Manage. 21:209-212.

Larson, J. 1982. History of the vegetative rehabilitation and equipment workshop 1946-1981. USDA Forest Service Bull. 2200.

Mueggler, W.F., and J.P. Blaisdell. 1958. Effects on associated species of burning, rotobeating, spraying, and railing sagebrush. J. Range Manage. 11:61-66.

Robertson, J.H. 1971. Changes on a sagebrush-grass range in Nevada ungrazed for thirty years. J. Range Manage. 24:397-400.

Thilenius, J.F., and G.R. Brown. 1974. Long-term effects of chemical control of big sagebrush. J Range Manage. 27:223-224.

Welch, B.L., and E.D. McArthur. 1979. Feasibility of improving big sagebrush (Artemisia tridentata) for use on mule deer winter ranges. p. 451-473. In: J.R. Goodin and D.K. Northington (eds.) Proc. Intern. Arid Lands Conf. on Plant Resources. Texas Tech Univ., Lubbock.

Wright, H.A., L.F. Neuenschwander, and C.M. Britton. 1979. The role and use of fire in sagebrush-grass and pinyon-juniper plant communities. $A$ state-of-the-art review. USDA Forest Serv. Gen. Tech. Rep. INT-58. 